Publisher homepage: www.universepg.com, ISSN: 2707-4641 (Online) \& 2707-4633 (Print) https://doi.org/10.34104/ijma.020.01310146

International Journal of Management and Accounting Journal homepage: www.universepg.com/journal/ijma

\title{
Investigation of Vegetable Market Integration System in Dhaka City: A Study on Effective Supply Value Chain Analysis
}

\section{Syed Moazzem Hossain ${ }^{1 *}$, Chinmoy Sarker ${ }^{2}$, Md. Moshiul Alam ${ }^{3}$, Kulsum Begum Chowdhury ${ }^{4}$, and Md. Ghyes Kamal ${ }^{5}$}

${ }^{1}$ Food Safety Specialist, International Development Group LLC, Dhaka, Bangladesh; ${ }^{2}$ Quality Control Manager, Mutual Food Products Ltd, Bangladesh; ${ }^{3}$ Senior Food Safety Specialist, International Development Group LLC, Dhaka, Bangladesh; ${ }^{4}$ National Value Chain \& Consumer Studies Specialist, FAO, Bangladesh; and ${ }^{5}$ Senior Customs Specialist, International Development Group LLC, Dhaka, Bangladesh.

*Correspondence: moazzem144@gmail.com (Syed Moazzem Hossain, Food Safety Specialist, International Development Group LLC, Gulshan-2, Dhaka-1212, Bangladesh).

\begin{abstract}
Vegetable cultivation in our country is growing day by day. We are now planting vegetables in our cultivable land area of 2.63 percent. Vegetables benefit farmers even more than other crops. It can play a vital role in improving the nutritional status of the chronically malnourished population of Bangladesh. There are various types of agricultural markets in Bangladesh through which agricultural products are traded. These are rural primary markets, rural assembly markets, rural secondary markets, and urban retail market. Before reaching the customers, vegetables are sold to wholesalers and retailers in Bangladesh. There is effectively a complete shortage of sophisticated vegetable handling equipment and facilities on the markets. Sorting, displaying, and selling are often performed from and into baskets at the ground level. Though Bangladeshi fruits and vegetables are exported to about 38 market destinations, the key buyers are primarily located in two regions: the United Kingdom and the Middle East. Bangladesh mostly exports fresh fruits and vegetables. However, during recent years export of processed as well as frozen vegetables had underway on a limited scale. The regular supply chain is for intermediaries to collect orders from exporters, go to production areas, collect crops from farmers/local markets, and arrange to deliver the same to exporters on the day of shipment. Owing to the opportunistic actions of sellers and consumers, the marketing cost rises, each seeking to take advantage of the other by means such as adulteration of the goods, cheating on weights and measures and violating distribution contracts. In Bangladesh, the vegetable marketing system is challenging, awkward, and unorganized and needs to be established for the well-being of common citizens.
\end{abstract}

Keywords: Vegetable market, Supply chain, Marketing system, Distribution, Analysis, and Dhaka

\section{INTRODUCTION:}

The City of Dhaka is currently home to over 16 million. The population is growing by an estimated 4.2 percent per year, one of the highest rates in Asia. The continuing growth is primarily the result of on-going migration from rural areas to the Dhaka metropolitan region, which accounted for 60 percent of the city's growth during the 1970s. More recently, the city's population has also grown with the UniversePG I www.universepg.com expansion of the city boundaries: a process that added more than 1 million people to the city in the 1980s. Dhaka will be home to 25 million individuals by the end of 2025, according to the Far Eastern Economic Review. Not unexpectedly, the extraordinary pace of urban development in Dhaka is leading to substantial environmental degradation and numerous social issues arising from unemployment, poverty, inadequate health care services, and poor 
sanitation (UNEP, 2015). It is currently estimated that some 12 percent of the urban population of Dhaka city live in informal low-income settlements (Hossain, 2011).

Rapid population growth and urbanization are also putting pressure on adjacent agricultural lands, water bodies, forest areas, and wetlands. Risks associated with Dhaka's unplanned urban growth are being further compounded by rapid industrialization and inadequate infrastructure investments, especially in transport (Hossain et al., 2019). Rising air and water pollution caused by traffic congestion and industrial waste are serious problems affecting public health and the city's quality of life. This led the Economist in 2015to rate Dhaka as the second least livable city in the world. Dhaka is also prone to serial disasters associated with flooding, water logging and related problems. Unplanned urbanization and the lack of coordination between government agencies are responsible for urban encroachment into the wetlands and the poor maintenance of the canal system. Agricultural land in Dhaka has a significant impact on flood control. Most of the agricultural lands are deluged and can retain water during monsoon (Rahman, 2016). However, the filling of the wetlands with sand and earth and the conversion of agricultural land to urban uses enhances the risk of flooding for the city, which impacts negatively upon both the availability and the affordability of fresh food. Despite massive immigration, it is apparent that the supply of food has increased in parallel with the accelerating rates of urban transformation, largely due to the inherent informality of the food marketing system (Bohle et al. 2010). However, the number of people who remain food insecure is an on-going concern. More than one quarter (28\%) of Dhaka's population live in severe poverty and are undernourished (World Bank, 2007).

According to the Bangladesh Urban Health Survey (2013), as many as 50 percent of the children in urban slums were stunted, in comparison with 33 percent among the residents of non-slum urban areas. According to Quasem, (2013), low-income households in Dhaka must often buy low quality food. Besides, new problems are emerging in the wake of urbanization, which although not unique to urban life, are especially relevant to it. These include: (a) poor food safety; (b) increasing obesity; and (c) the increasing difficulty of combining the pursuit of work outside the home with care giving, which is essential for the nutritional well-being of children (WFP, 2016). Chronic food insecurity is thus a reality for a large proportion of the urban population in the city of Dhaka. The resilience of the food system of Dhaka, in terms of food utilization, is difficult to judge as people's food consumption is not only driven by the availability and accessibility of food, but also by social discourses about food and by people's own needs and desires (Bohle et al., 2010). Most of the transactions in Dhaka's food system are informal as is the governance of wholesale food markets and street food vendors. Policymakers and urban planners need to take into account that informality is an inherent part of a functional and resilient urban food system (Quddus, 2013).

According to Bohle et al. (2010), the city of Dhaka is well supplied with food, as the availability of staples is well above the national average. Every day, over 9,000 tons of rice, fish, pulses, spices, fruit, vegetables, edible oil, meat, eggs, and wheat are brought into Dhaka and distributed through the marketing system. However, while food might be available, it is unlikely to be affordable to all income groups. Unnayan Onneshan, (2004) reported that food prices are increasing due to extortion, the high cost of transport, high lending rates for credit, and the presence of marketing cartels. Regrettably, it seems, extortion and exploitation are spreading among toll collectors and members of the law enforcement agencies.

Saleh, (2014) attribute the major causes of food price inflation to man related causes, process-related causes, material related causes, transportation-related causes, and environment related causes. There is an immediate need for identifies entry points for policies that build on rural-urban interdependencies and synergies to foster an enabling environment for smallholder farmers to participate more equitably in food chains whilst simultaneously encouraging consumers to make more informed food choices. This study has been analysed the vegetable value chain to identify different impediments and opportunities to improve the entire value chain performance in Dhaka city. Besides, this study will support to develop of an appropriate food agenda for the city of Dhaka by building the urban food planning capacity and will explore the policy options to improve access to and the distribution of safe, heal- 
thy, and nutritious food, reduce urban food waste and encourage consumers at all levels of society to make more informed food choices. From the above viewpoints, the present study attempts to depict the following objectives:

- To review the production level and consumption rate of vegetables in Bangladesh;

- To review the possible impediments of vegetable production to distribution;

- To highlight the different marketing system of vegetables in Bangladesh.

\section{MATERIALS AND METHODS:}

This paper is based on the value chain approach, focusing on intermediary activities, products, and cost flow. This study is conducted in peri-urban areas (Keranigonj, Gazipur, Savar and Manikgonj) near Dhaka city and Dhaka city (Karwan Bazar, Mohammadpur Katcha Bazar, Mirpur-1 Katcha Bazar, Uttara, and Banani Residential Areas) for the vegetable supply chain. The value chain study follows both quantitative and qualitative methods for data collection. The study is fully participatory through ensuring maximum involvement of farmers, wholesalers, retailers, street vendors, and restaurants. However, the research paper is considered a mix of an in-depth interview, focus group discussion, projective technique, and observation technique. The necessary steps required to perform the case study are presented below.

Primary investigation - Considering the availability and huge production of vegetables in peri-urban areas are selected as the study area. Primarily vegetable supply chain from these peri-urban areas towards Dhaka is set as an investigation chain to develop a general understanding of the opportunities on the research objectives.

Literature review - To gain sufficient knowledge on value chain analysis and vegetable supply chain analysis, a few books, articles, research papers, and project reports are collected and studied.

Preparing the primary questionnaire - After a primary investigation and literature review, a set of a primary questionnaire is prepared for farmers, wholesalers, retailers, street vendors, and restaurants. Primary tools and techniques for analysis are also selected.

Investigation through the literature - A field visit is conducted after preparing the primary questionnaire, and this questionnaire is based on the value chain analysis technique and research objectives.

Preparing the final questionnaire - The final questionnaire is prepared after an investigation. During this phase, the final tools for field investigation and interviews with the key informants and market actors are designed. The final questionnaire, tools, and technique are then used for the study and analysis.

Data collection - Finally, data are collected through observation and questionnaire. Data are collected from both primary and secondary sources. Primary data are collected directly from an interview and group discussion of respondents. Secondary data are collected from the Bureau of Statistics (BBS), DAE, newspaper and internet files, etc. In analysing vegetable supply chains in Dhaka, four focus group discussions (FGDs) were conducted with 24 vegetable farmers in the peri-urban districts of Gazipur, Keranigonj, Manikgonj, and Savar (Table 1).

Table 1: Type and number of respondents

\begin{tabular}{|c|c|c|}
\hline $\begin{array}{l}\text { Value Chain } \\
\text { Actors }\end{array}$ & Major Role & $\begin{array}{l}\text { No of the respondents } \\
\text { based on the survey }\end{array}$ \\
\hline $\begin{array}{l}\text { Vegetable } \\
\text { farmer }\end{array}$ & $\begin{array}{l}\text { Farmers are the producer of the vegetable. They produce different types of } \\
\text { vegetables and bring their product to sell in their local market. The amount } \\
\text { and types of vegetables differ from season to season. }\end{array}$ & 24 \\
\hline Wholesalers & $\begin{array}{l}\text { The wholesalers (locally known as many names like paikers, bepari, or } \\
\text { mokami) play a significant role in the vegetable marketing system. }\end{array}$ & 16 \\
\hline Retailers & $\begin{array}{l}\text { Retailers are directly linked to the consumer. They purchase their product } \\
\text { from the wholesale market and sell it to the consumer. }\end{array}$ & 50 \\
\hline Street vendor & Street vendors sell vegetables door-to-door primarily in residential areas. & 19 \\
\hline Restaurants & $\begin{array}{l}\text { Restaurants prepare and serve food and drinks to customers in exchange for } \\
\text { money. }\end{array}$ & 28 \\
\hline
\end{tabular}


Face-to-face executive interviews were subsequently conducted with wholesalers (16), retailers (50), street vendors (19), and restaurants (28) in the city of Dhaka. Given the need to gather specific information of prices and volumes, the seasonality of supply, storage, and product wastage, the study focused on three products: (i) spinach (pui-shak)- a green leafy vegetable; (ii) potato- a root crop; and (iii) eggplant (Brinjal)- a fruit crop.
Data processing and analysis - The informational data collected are sorted and arranged so that further study and analysis could be performed. Quantitative data are arranged by using graphs and tables. Various types of information are given as a profile. Data are analyzed by using pie charts, cause-effect analysis, flow charts, process tree, etc. The data that have been obtained by interviews, questionnaires, and observations are structured in an order. After completion of the data processing, the analysis has been performed.

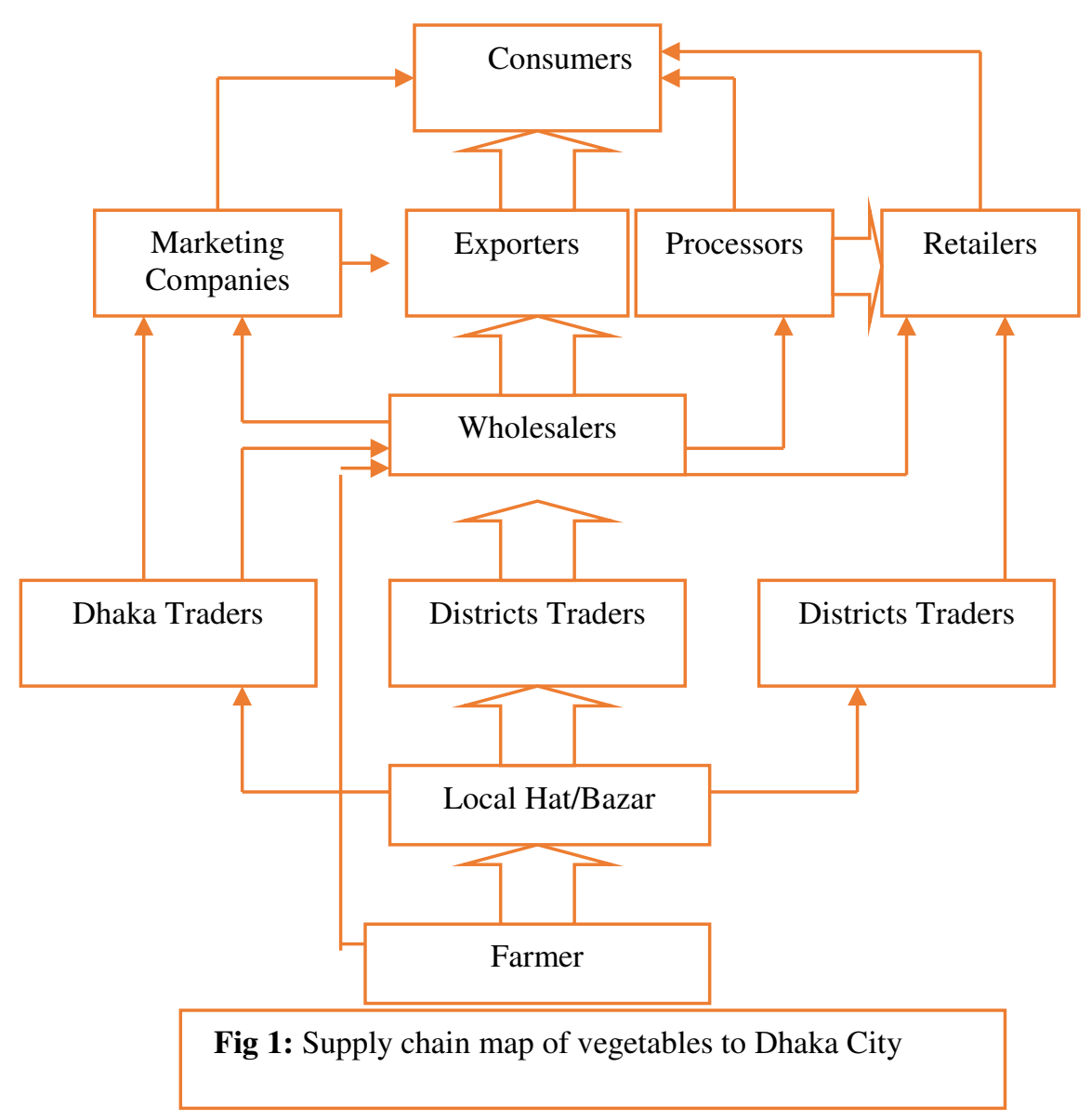

\section{RESULTS AND DISCUSSION:}

Present Supply Value Chain Map - The value chain map shows the movement of the vegetable product among the supply chain and identifies the actors and their activities. In the present supply chain, illustrates in Fig $\mathbf{1}$ identify the major channel of the vegetable supply chain in Bangladesh. The value chain starts with the producer and end at consumers. From producer to consumer, the product follows a lengthy market channel. Different market actors are known as market intermediaries or stakeholders involve in this value chain. Other market intermediaries are the local wholesaler, divisional wholesaler, the regional wholesaler, and retailer.

UniversePG I www.universepg.com
The two main problems that farmers faced in growing fresh vegetables in the peri-urban areas were the non-availability of labour (75\%) and the fluctuation in output prices (a sudden price drop) (75\%), (Table 2). As per the discussions with farmers through focus group discussions (FGDs), most vegetable growers reported a scarcity of labour for the cultivation, harvesting, and post-harvest processing (sorting, grading, and packing) of their vegetable crops. As wages for agricultural labourers were very low, the resource had been diverted to other industrial sectors. According to Islam and Uchiyama, (2012), vegetable production requires at least 50 percent more labour than cereal production. 
Besides, agricultural work is not constant all year round as it is dependent on the seasonality of vegetable cultivation. For the few available workers, the cost of labour was rising. Islam and Uchiyama, (2012) have similarly reported that the high cost of labour was an issue in vegetable cultivation, for labour was often the single highest cost item (33.6\% of total costs).

Table 2: Constraints faced by the farmers in commercial cultivation of vegetable in pre-urban areas

\begin{tabular}{|c|c|}
\hline Constraints of vegetable farmers & Respondent (\%) \\
\hline High labour costs & 75 \\
\hline $\begin{array}{l}\text { Price fluctuation (Sudden drop of } \\
\text { price) }\end{array}$ & 75 \\
\hline $\begin{array}{l}\text { Loans are not available and have } \\
\text { less knowledge about the loan }\end{array}$ & 50 \\
\hline The low price of products & 50 \\
\hline $\begin{array}{l}\text { Unavailability of agricultural } \\
\text { inputs }\end{array}$ & 50 \\
\hline $\begin{array}{l}\text { Lower quality \& mixed seed found } \\
\text { in private company seeds }\end{array}$ & 50 \\
\hline Flash flood & 50 \\
\hline $\begin{array}{l}\text { No training on the safe use of } \\
\text { insecticides }\end{array}$ & 50 \\
\hline $\begin{array}{l}\text { High Interest in other non-banking } \\
\text { loans }\end{array}$ & 50 \\
\hline Sudden rain & 25 \\
\hline $\begin{array}{l}\text { The high price of agricultural } \\
\text { inputs }\end{array}$ & 25 \\
\hline $\begin{array}{l}\text { Unable to get expected prices at the } \\
\text { bazaar }\end{array}$ & 25 \\
\hline Marginal farmer & 25 \\
\hline Low land & 25 \\
\hline No separate markets for farmer & 25 \\
\hline $\begin{array}{l}\text { Need to pay to local leaders to sell } \\
\text { products in roadside }\end{array}$ & 25 \\
\hline Attack of insects & 25 \\
\hline $\begin{array}{l}\text { No facilities for storage of } \\
\text { vegetables }\end{array}$ & 25 \\
\hline
\end{tabular}

The main two problems the farmers faced for growing the vegetables in peri-urban areas were high labour cost $(75 \%)$ and price fluctuation (Sudden price drop) (75\%). As per the discussion with the farmers' group through FGD, most of the growers in those areas said labour was scarce during the vegetable cultivation, harvesting, processing, and postharvesting time. Nowadays most of the labour is diverted from their agricultural occupation to other sectors due to having nominal wages in agricultural works. According to Hasan et al. (2012), vegetable production requires at least $50 \%$ more human labour compared with cereal production (which among the concerns mentioned above will, on the other hand, obviously increase farm-labour jobs). Besides, the agricultural works are not fixed round the year as it is depending on the seasonality of vegetable cultivation, hence bound them to divert their main occupation to another profession. Although few workers are available to work during the vegetable growing period, their labour cost is higher than other professions in that particular time. The finding also supports the study of Islam et al. (2012) that the high cost of labour was one of the issues in vegetable cultivation and it was the single highest-cost item, at $33.61 \%$ of the total cost.

A sudden drop in vegetable price is another constraint of farmers as the prices of vegetables fluctuated very frequently in the market. Farmers are sometimes baffled when they would be harvesting of their products for selling. The production cost was about three times higher in vegetables than in cereals but when the farmers were gone to sell their products in the market; the market price is dramatically dropped due to lack of proper price monitoring capacity by the government. Farmers cannot anticipate future market prices at the time of planting and have only a limited ability to postpone sales when prices are unfavourable, as most perish-able vegetables cannot store for more than a few days. They were not got the right price value of their products at that time and incurred a huge amount of losses as they were bound to sell all of their perishable vegetables instantly, otherwise, it would be damaged or spoiled. Moreover, there was no adequate cold storage to store these perishable vegetables for a longer period. As per the finding of Islam et al. (2012), there is wide seasonal fluctuation in the price of vegetables, and price variation is one of the main risks' vegetable growers face.

The second most constrain faced by the farmers was unavailability to get agricultural loans from the government or commercial bank in the cultivation period due to lack of knowledge for loan sanction (50\%). Most of the farmers in Bangladesh are uneducated and due to not having the proper knowledge to understand the entire process of loan 
sanction procedure from the governmental or commercial banks, they had to manage the loan through few middlemen in the bank office or other persons of outsides. To get the loan on time, they had to provide a certain amount of bribe or commission to these middle men; otherwise, they were deprived to get the loan. Besides, another problem faced by the growers is the low price of products round the year $(50 \%)$ and unavailability of agricultural inputs like fertilizer, manure, insecticide, pesticide, irrigation, and so forth (50\%).

The BADC (Bangladesh Agriculture Development Corporation) provides the necessary agricultural inputs to the farmers which quality is better than other sources but the quantity of these inputs was too nominal to distribute to all of the farmers. In this circumstance, they had to manage their inputs from other sources like the private company where the price of these inputs was higher than BADC. However, $50 \%$ of farmers are not happy with the quality of these agricultural inputs collected from a private company as in most cases, the seeds are mixed with inner material or extraneous matter which are in low quality to germinate. Moreover, $50 \%$ of farmers are affected by a flash flood during the time of monsoon. At that time, the cultivable land for vegetables was inundated with floodwater in low lying areas in Bangladesh. Farmers are not cultivated their land and incurred a huge loss.

The data also supported another one qualitative study in Kalatia Village at Keranijong conducted by Islam and et al. (2012) where they found the main problems for vegetable production in Kalatia are related to flooding and flood-waters could damage or destroy their entire crop. Another one issue of the farmers is the high interest in the loan (50\%) which was a full burden to manage these high amounts rate end of the year. There are others constraints faced by the growers, sudden rain in monsoon $(25 \%)$, the higher price of agricultural inputs (25\%), not getting expected vegetable price from the customers $(25 \%)$, no separate vegetable market $(25 \%)$, the infestation of insects and pest (25\%), etc (Temesgen, 2020).

\section{Wholesalers, Street Vendors, and Restaurants -}

All wholesalers, street vendors, and restaurants purchased fresh vegetables every day. However, some $2 \%$ of retailers purchased 2-3 times a week and $2 \%$ purchased only 2-3 times per month (Table 3 ).

Table 3: Frequency of purchased the vegetables by different actors

\begin{tabular}{|l|c|c|c|c|}
\hline \multirow{2}{*}{ Frequency } & \multicolumn{4}{|c|}{ Percent } \\
\cline { 2 - 5 } & Wholesale & Retailer & Street vendor & Restaurants \\
\hline Everyday & 100 & 96 & 100 & 100 \\
\hline 2-3 times a week & - & 2 & - & - \\
\hline Once a week & - & - & - & - \\
\hline 2-3 times a month & - & 2 & - & - \\
\hline Once a month & - & - & - & \\
\hline
\end{tabular}

Table 4: Quantity purchased and sold of vegetable with its losses (\%)

\begin{tabular}{|c|c|c|c|c|c|c|c|c|}
\hline \multicolumn{9}{|c|}{ Mean amount (kg/week) } \\
\hline \multirow[t]{2}{*}{ Types of Actors } & \multicolumn{2}{|c|}{ Aggregated Vegetable } & \multicolumn{2}{|c|}{ Potato } & \multicolumn{2}{|c|}{ Brinjal } & \multicolumn{2}{|c|}{ Spinach } \\
\hline & Purchased & Sold & Purchased & Sold & Purchased & Sold & Purchased & Sold \\
\hline Wholesaler & 21546 & 24445 & 32279 & 38930 & 1340 & 1288 & 100 & 100 \\
\hline Losses $(\%)$ & \multicolumn{2}{|c|}{$*$} & \multicolumn{2}{|c|}{0} & \multicolumn{2}{|l|}{4} & \multicolumn{2}{|c|}{0} \\
\hline Retailer & 1693 & 1662 & 3387 & 3438 & 142 & 135 & 130 & 126 \\
\hline Losses $(\%)$ & \multicolumn{2}{|c|}{2} & \multicolumn{2}{|c|}{0} & \multicolumn{2}{|l|}{5} & \multicolumn{2}{|c|}{3} \\
\hline Street Vendor & 498 & 466 & 128 & 128 & 78 & 77 & 95 & 95 \\
\hline Losses $(\%)$ & \multicolumn{2}{|c|}{6} & \multicolumn{2}{|c|}{0} & \multicolumn{2}{|l|}{1} & \multicolumn{2}{|c|}{0} \\
\hline Restaurant & 105 & 105 & 50 & 50 & 0 & 0 & 0 & 0 \\
\hline Losses $(\%)$ & \multicolumn{2}{|c|}{0} & \multicolumn{2}{|c|}{0} & \multicolumn{2}{|l|}{$*$} & \multicolumn{2}{|c|}{$*$} \\
\hline
\end{tabular}


The average quantity of fresh vegetables purchased per week by wholesalers was $21546 \mathrm{~kg}$, with retailers purchasing an average of $1693 \mathrm{~kg}$, street vendors $498 \mathrm{~kg}$, and restaurants $105 \mathrm{~kg}$ (Table 4).

Wholesaler's average purchasing $(21546 \mathrm{~kg})$ and selling $(24445 \mathrm{~kg})$ amount of aggregated vegetables in a week is higher rather than other actors, though the sold quantity of vegetables shows higher than the purchased quantity because the respondents were declared the sold quantities with an opening balance of the previous day. There was a $2 \%$ loss of total vegetables per week when it was moved to the retailer's hand and a $6 \%$ loss has occurred in the case of street vendors. It was deemed that most of the cases, street vendors have not enough shelter to protect their perishable vegetable from drying up during carrying of their products in the road or street and have not available storage facilities to keep retain of their unsold vegetables for the next day. So, normally they discarded or used these unsold vegetables for their purpose end of the day. On the other hand, as the restaurant used all of their purchased vegetables on the same day for restaurant purposes, hence there were no losses.
In the case of potato, there were no losses found form each of the actors while a similar situation was observed in the context of wholesaler and retailer like the aforementioned of aggregated vegetable, the sold amount per week is higher than the amount of purchase due to considering the previous day's opening balance. On the other hand, street vendors and restaurants are sold all amount of their products on the same day, hence there is no loss.

On the contrary, in the case of brinjal, the losses amount per week is higher than potato while the number of losses by a wholesaler, retailer, and the street vendor is $4 \%, 5 \%$, and $1 \%$ respectively. In addition, the retailer's losses also higher than that of wholesalers because they were selling all of their brinjals on the same day and not kept leftovers for the next day. But the retailer was not sold all of their brinjals in the same day and kept unsold brinjal in storage where they piled up it haphazardly. A similar situation was observed in the case of spinach where $3 \%$ of losses were happening by retailers and there were no losses in street vendors and retailers.

Table 5: Mean value of vegetable purchased and sold with its sales margin (\%)

\begin{tabular}{|c|c|c|c|c|c|c|c|c|}
\hline \multicolumn{9}{|c|}{ Mean price (BDT/kg) } \\
\hline \multirow[t]{2}{*}{ Types of Actors } & \multicolumn{2}{|c|}{$\begin{array}{c}\text { Aggregated } \\
\text { Vegetable }\end{array}$} & \multicolumn{2}{|c|}{ Potato } & \multicolumn{2}{|c|}{ Brinjal } & \multicolumn{2}{|c|}{ Spinach } \\
\hline & Purchased & Sold & Purchased & Sold & Purchased & Sold & Purchased & Sold \\
\hline Wholesaler & 26 & 28 & 11 & 13 & 49 & 54 & 10 & 12 \\
\hline Sales Margin (\%) & \multicolumn{2}{|c|}{8} & \multicolumn{2}{|c|}{18} & \multicolumn{2}{|c|}{10} & \multicolumn{2}{|c|}{20} \\
\hline Retailer & 36 & 48 & 20 & 25 & 56 & 69 & 23 & 30 \\
\hline Sales Margin (\%) & \multicolumn{2}{|c|}{33} & \multicolumn{2}{|c|}{25} & \multicolumn{2}{|c|}{23} & \multicolumn{2}{|c|}{30} \\
\hline Street Vendor & 36 & 48 & 16 & 20 & 47 & 63 & 22 & 28 \\
\hline Sales Margin (\%) & \multicolumn{2}{|c|}{33} & \multicolumn{2}{|c|}{25} & \multicolumn{2}{|c|}{34} & \multicolumn{2}{|c|}{27} \\
\hline Restaurant & 70 & & 20 & & 0 & & 0 & \\
\hline Sales Margin (\%) & \multicolumn{2}{|c|}{$*$} & \multicolumn{2}{|c|}{$*$} & \multicolumn{2}{|c|}{$*$} & \multicolumn{2}{|c|}{$*$} \\
\hline
\end{tabular}

The average purchasing price of aggregated vegetables by wholesalers was $26 \mathrm{tk} / \mathrm{kg}$ and the sold price was $28 \mathrm{tk} / \mathrm{kg}$, where the sales margin is $8 \%$. But on the contrary, the sales margin was dramatically increased (33\%) when aggregated vegetables handed over to the retailer from the wholesaler. Besides, the same activity has happened in the context of street vendor people as well while their gross profit or sales margin almost the same as the retailer (33\%).
However, restaurant people purchased the total vegetable in $70 \mathrm{tk} / \mathrm{kg}$ but there was no value data of sales as they used all aggregated vegetables for their business consumption, it could not possible to show the gross profit margin in their end. In the case of potato, the sales margin of the wholesaler is $18 \%$ but when the products were handed over to the retailer and street vendor, the sales margin was gone up 25\% and $25 \%$ respectively. A restaurant has no value data 
of sales; it was not possible to figure out the sales margin of their end.

In the context of brinjal, the highest sales margin (34\%) was achieved by the street vendor where the sales margin of wholesaler and retailer was $10 \%$ and $23 \%$ respectively. The overall sales margin is increased step by step moving product from wholesaler to a street vendor, though both street vendors and retailers have purchased brinjal from the same or different wholesaler. In the case of spinach, the retailer sales margin (30\%) is higher than that of wholesaler (20\%) and street vendor (27\%), though there was not value data of spinach sales, hence could not possible to figure out the sales margin from their end.

The net profit of wholesalers is $2.75 \%$ by selling all types of vegetables where the net profit of retailer and street vendor is $14.87 \%$ and $11.90 \%$ respectively which are four times higher than that of wholesalers (Table 6).

Table 6: Net profitability of different vegetable actors (BDT/month)

\begin{tabular}{|l|c|c|c|c|c|}
\hline \multicolumn{1}{|c|}{$\begin{array}{c}\text { Types of } \\
\text { Actors }\end{array}$} & $\begin{array}{c}\text { Total purchase } \\
\text { value (BDT/month) } \\
\text { (A) }\end{array}$ & $\begin{array}{c}\text { Total sold value } \\
\text { (BDT/month) }(\mathbf{B})\end{array}$ & $\begin{array}{c}\text { Total business } \\
\text { cost } \\
\text { (BDT/month) }(\mathbf{C})\end{array}$ & $\begin{array}{c}\text { Net profit } \\
\text { (BDT/month) } \text { (B- } \\
(\mathbf{A}+\mathbf{C}) \boldsymbol{\}}\end{array}$ & $\begin{array}{c}\text { Profit } \\
(\boldsymbol{\%})\end{array}$ \\
\hline Wholesale & 2240784 & 2424912 & 122421 & 61707 & 2.75 \\
\hline Retail & 243792 & 319104 & 39054 & 36258 & 14.87 \\
\hline Street vendor & 71712 & 89472 & 9222 & 8538 & 11.90 \\
\hline
\end{tabular}

Table 7: The distance of the carrying vegetables

\begin{tabular}{|l|c|c|c|c|}
\hline \multirow{2}{*}{ Types of Actors } & \multicolumn{2}{|c|}{ Percent } & \multicolumn{2}{c|}{ Distance [km] } \\
\cline { 2 - 5 } & Collect & Deliver & Mean & SD \\
\hline Wholesale & 20 & 80 & 63 & 90 \\
\hline Retailer & 100 & 0 & 4 & 5.7 \\
\hline Street vendor & 100 & 0 & 3.30 & 4.6 \\
\hline Restaurant & 100 & 0 & 1 & 1 \\
\hline
\end{tabular}

Table 8: Mode of Transport

\begin{tabular}{|l|c|c|c|c|}
\hline \multirow{2}{*}{ Types of Transport } & \multicolumn{4}{|c|}{ Mode of transport [percent] } \\
\cline { 2 - 5 } & Wholesale & Retailer & Street vendor & Restaurant \\
\hline Truck & 62 & 0 & 0 & 0 \\
\hline Headload & 0 & 18 & 10 & 0 \\
\hline Pick up & 38 & 33 & 5 & 0 \\
\hline Rickshaw & 0 & 23 & 11 & 0 \\
\hline Van & 0 & 22 & 74 & 100 \\
\hline Others & 0 & 4 & 0 & 0 \\
\hline
\end{tabular}

Normally, most of the cases vegetables are delivered $(80 \%)$ to the wholesaler in Dhaka city from different traders or farmers of rural or pre-urban areas in Bangladesh where the average delivery distance is $63 \mathrm{~km}$, though the standard deviation is higher than the average because few vegetables were delivered or collected form shorter distance where some of were from long distance. On the other hand, all of the retailers were collected the vegetables $(100 \%)$ from different wholesalers in Dhaka city where the average distance was $4 \mathrm{~km}$. Similarly, a street vendor was collected from their vegetables from the same wholesalers wherefrom the retailer was purchased or from the different wholesalers. Restaurants are also collected all of their daily vegetables either from a retailer or wholesaler nearer to their restaurant (Table 8).

The finding shows that wholesalers are normally used trucks $(62 \%)$ to carry their vegetables for bringing in Dhaka city from a long-distance followed by pick up (38\%). As they brought the product from a far distance, there is no chance to use other nonmotorized vehicles at all. On the contrary, retailers 
were preferred to pick up (33\%), rickshaw (23\%), van $(22 \%)$ for the long-distance, and head load $(18 \%)$ for the short distance. Conversely, street vendors are normally selling fresh vegetables with their van in Dhaka city; hence, they do not need any other support to carry the products. So, most of the time they used their van for carrying vegetables (74\%). Rickshaw (11\%) and head load (10\%) another preference to carry the products within a short distance. The respondents of the restaurant are fully dependent on the van (100\%) as they normally carry all types of commodities at a time for their purpose of restaurant. Van is more suitable rather than other transport in the case of a restaurant.
Table 9: Quantity consistent (\%)

\begin{tabular}{|l|c|c|c|c|}
\hline \multicolumn{5}{|c|}{ Quantity consistent all year round [percent] } \\
\hline & Wholesale & Retailer & Street vendor & Rest. \\
\hline Yes & 0 & 0 & 0 & 0 \\
\hline No & 100 & 100 & 100 & 100 \\
\hline
\end{tabular}

All the respondents of Wholesalers, retailers, street vendors \& restaurants responded that the quantity supplied to the market is not consistent (100\%) all the year-round. All of the respondents said that vegetables were most plentiful in winter and low in autumn. Fortuitously, the high demand season for vegetables was also in winter.

Table 10: Demand and Supply status of vegetables in Dhaka City

\begin{tabular}{|c|c|c|c|c|}
\hline \multirow{3}{*}{ Types of actors } & \multicolumn{4}{|c|}{ Months } \\
\hline & \multicolumn{2}{|c|}{ Supply } & \multicolumn{2}{|c|}{ Demand } \\
\hline & Low & High & Low & High \\
\hline Wholesale & Autumn & Winter & Never & Winter \\
\hline Retailer & Autumn & Winter & Never & Winter \\
\hline Street vendor & Autumn & Winter & Never & Winter \\
\hline
\end{tabular}

All of the actors were respondents that the high supply time of vegetables in Dhaka city was winter and the low supply season was autumn. On the contrary, the high demand month was winter and there was no specific time for low demand for vegetables means round the year there was the demand for vegetables in Dhaka city. The above result supports the previous findings of Biswas, (2012) that there are plenty of winter vegetables grown in Bangladesh but there are few vegetable crops/varieties available in the monsoon season. For this reason, in the monsoon season, the supply of vegetables in the market is very limited and vegetable prices are often higher than what consumers are willing to pay (Table 10).

Table 11: Criteria for selection of suppliers (\%)
Most of the wholesaler respondents said that they had selected the supplier for vegetables based on low price and cost (40\%) and quality of the vegetable (40\%) followed by varieties of products $(20 \%)$ and its size (20\%). On the other hand, the majority of retailers were stated that they had preferred the low price $(90 \%)$ of vegetables when they dealing with suppliers followed by its quality $(44 \%)$, variety (33\%), and freshness (13\%). Besides, $90 \%$ of the street vendors were given priority of low cost and price along with quality (74\%). In respect of restaurants, $50 \%$ of respondents were preferred to deal with vegetable wholesalers or retailers for low cost, and 50\% were given priority on quality (Table 11).

\begin{tabular}{|l|c|c|c|c|}
\hline \multirow{2}{*}{ Types of Preferences } & \multicolumn{3}{|c|}{ Percent [of respondents] } \\
\cline { 2 - 5 } & Wholesale & Retailer & Street Vendor & Restaurant \\
\hline Low Price/ Cost & 40.00 & 80.43 & 89.47 & 50.00 \\
\hline Quality & 40.00 & 43.48 & 73.68 & 50.00 \\
\hline Variety & 20.00 & 32.61 & 10.53 & 0.00 \\
\hline Freshness & 0.00 & 13.04 & 15.79 & 0.00 \\
\hline Availability & 10.00 & 4.35 & 10.53 & 0.00 \\
\hline Good Reputation & 0.00 & 0.00 & 0.00 & 0.00 \\
\hline Competitive Price & 0.00 & 6.52 & 0.00 & 0.00 \\
\hline Size & 20.00 & 0.00 & 5.26 & 0.00 \\
\hline Less Damaged Product & 0.00 & 4.35 & 10.53 & 0.00 \\
\hline
\end{tabular}




\begin{tabular}{|l|c|c|c|c|}
\hline Choose Different Suppliers & 0.00 & 0.00 & 5.26 & 0.00 \\
\hline Good Service & 10.00 & 2.17 & 0.00 & 0.00 \\
\hline Distance & 0.00 & 4.35 & 0.00 & 0.00 \\
\hline Seasonality & 10.00 & 0.00 & 0.00 & 0.00 \\
\hline
\end{tabular}

Table 12: Payment methods of different actors

\begin{tabular}{|l|c|c|c|c|}
\hline \multirow{2}{*}{ Types of Transaction } & \multicolumn{3}{|c|}{ Payment system Percent [of respondents] } \\
\cline { 2 - 5 } & Wholesale & Retailer & Street vendor & Restaurant \\
\hline Cash & 88 & 90 & 100 & 100 \\
\hline Credit & 6 & 10 & - & - \\
\hline Instalments & - & - & - & - \\
\hline Mobile Transaction & - & - & - & - \\
\hline Check & - & - & - & - \\
\hline Online Transaction & - & - & - & - \\
\hline Others & 6 & - & - & - \\
\hline
\end{tabular}

Most of the actors involved in the vegetable trade normally transacted with cash when they purchased or sold. Street vendors and restaurants only transacted in cash as the number of vegetables they have purchased and sold was low quantity rather than that of wholesalers and retailers. Conversely, wholesalers and retailers had to purchase or sell a big amount value of vegetables rather than other actors, hence $6 \%$ of wholesalers and $10 \%$ of retailers are needed to transact with credit (Table 12). These findings are supported by Ahmed, (2014) who found that vegetable retailers have to buy their product in cash. They seldom get any credit from the wholesaler.

In transporting fresh produce, most of the wholesalers experienced some problems with traffic jams $(73 \%)$ on the road, followed by the long delivery time $(27 \%)$. They also faced difficulties in terms of traffic accidents (9\%) and the nonavailability of transport (9\%), (Table 13). The finding also supports the study of Hassan, (2013), that the main problems in transportation were related to the lack of farm roads, broken and uneven roads and highways, lack of coordination in transport agencies, high damages during transportation, and slow movement in transportation due to traffic congestions. Many of the retailers (23\%) experienced problems associated with police bribery, followed by traffic jams (20\%), road accidents, and the high cost of transport (13\%). They also experienced problems with the long delivery time (8\%). Ahmed (2014) revealed that retailers and street vendors were struggling to carry their products from the wholesale market to the retail market because they did not have any permanent transport service. Street vendors often experienced traffic jams (18\%) and road accidents (18\%) as most of them were transporting the vegetables in their cart or rickshaw.

Table 13: Problem experienced in purchasing the vegetable (\%)

\begin{tabular}{|l|c|c|c|c|}
\hline \multirow{2}{*}{ Types of problem } & \multicolumn{3}{|c|}{ Percent [of respondents] } \\
\cline { 2 - 5 } & Wholesale & Retailer & Street Vendor & Restaurant \\
\hline No Problem & 9.09 & 30.77 & 35.29 & 30.77 \\
\hline Traffic jam & 72.73 & 20.51 & 17.65 & 30.77 \\
\hline Bribing by Police & 0.00 & 23.08 & 0.00 & 0.00 \\
\hline Accident & 9.09 & 12.82 & 17.65 & 0.00 \\
\hline Long Delivery Time & 27.27 & 7.69 & 5.88 & 15.38 \\
\hline High Transport Fare & 0.00 & 12.82 & 0.00 & 38.46 \\
\hline Transport Availability & 9.09 & 2.56 & 5.88 & 23.08 \\
\hline Only Rickshaw & 0.00 & 5.13 & 0.00 & 0.00 \\
\hline Transport Manage & 0.00 & 0.00 & 0.00 & 0.00 \\
\hline
\end{tabular}

UniversePG I www.universepg.com 


\begin{tabular}{|l|c|c|c|c|}
\hline Shared Vehicle & 0.00 & 5.13 & 5.88 & 0.00 \\
\hline Restriction on vehicle Movement on some road & 0.00 & 0.00 & 11.76 & 0.00 \\
\hline Overloading & 0.00 & 2.56 & 0.00 & 0.00 \\
\hline Open Vehicle & 0.00 & 0.00 & 5.88 & 0.00 \\
\hline Vegetables dry up & 0.00 & 0.00 & 5.88 & 0.00 \\
\hline Rules Regulation & 0.00 & 0.00 & 5.88 & 0.00 \\
\hline Security issue & 0.00 & 2.56 & 0.00 & 0.00 \\
\hline Broken Road & 0.00 & 2.56 & 0.00 & 7.69 \\
\hline Snatching & 0.00 & 2.56 & 0.00 & 0.00 \\
\hline Distance & 0.00 & 0.00 & 5.88 & 0.00 \\
\hline
\end{tabular}

They also experienced problems every day in the restriction of vehicle movements on some roads in Dhaka. In some residential areas, the respective housing society allowed nominated street vendors to conduct their business, but they had to abide by the rules imposed by the housing society and needed to display notice of approval when they moved into the restricted area. Some 6\% of respondents said they were sometimes harassed with different rules and regulations imposed by the government, vegetables drying up due to open transport (6\%), managing a shared vehicle with other vendors $(6 \%)$, distance to the wholesale market (6\%) and the lack of transport other than rickshaws for carrying small quantities of vegetables $(6 \%)$.

Restaurant owners stated that they faced the problem of high transport cost (38\%) to carry the products from the market to their place of business, followed by acute traffic jam (31\%), long delivery time (15\%), and the lack of transport (23\%). 56\% wholesaler has no storage capacity in their end as most of the time they sold vegetables to other actors on the same day, whereas $44 \%$ of respondents were said they have storage facilities. As all of the retailers need to store the products for selling it the next day, all of them have adequate storage facilities. In the context of the street vendor, $60 \%$ were said they have storage to keep the leftover vegetable but all of the restaurants said that they have no adequate storage facilities as

Table 15: Food wastage after storage

Table 15: Food wastage after storage
\begin{tabular}{|l|c|c|c|c|}
\hline Types of Actor & Duration(Days) & Storage Quantity (Kg) & Losses (kg) & Losses [\%] \\
\hline Wholesale & 1 & 124 & 6 & 5 \\
\hline Retailers & 1.5 & 75 & 4 & 6 \\
\hline Street vendors & 1 & 12 & 1.8 & 15 \\
\hline Restaurants & 0 & 0 & 0 & 0 \\
\hline
\end{tabular}

they used all of the vegetables on the same day for restaurant purposes (Table 14).

Table 14: Value chain actors store vegetable (\%)

\begin{tabular}{|l|c|c|}
\hline \multirow{2}{*}{ Types of actors } & \multicolumn{2}{|c|}{ Storage Capacity } \\
\cline { 2 - 3 } & Yes & No \\
\hline Wholesale & 44 & 56 \\
\hline Retailers & 100 & 0 \\
\hline Street vendors & 60 & 40 \\
\hline Restaurants & 0 & 100 \\
\hline
\end{tabular}

Post-harvest losses for vegetables in Bangladesh are estimated to be 20 to $25 \%$. For highly perishable fruit and vegetables, these losses may be as high as 40\% (Badruddoza and Rolle, 2006). Lack of appropriate storage facilities is seen as a factor that contributes to these losses (Hassan et al., 2010). Storage facilities should be located at each of the loading and unloading points, as well as in the wholesale markets. The absence of such facilities was identified as a critical problem in the present marketing system. For the wholesalers, the main problems they experienced in their transactions with suppliers were damage due to overloading (50\%). The second and third most frequently cited reasons for the damage to vegetables was inadequate knowledge of loading and unloading (25\%) and insufficient storage facilities (25\%). Others attribute leading to product damage included high temperature (12\%) and the lack of labour (12\%), (Table 15). 
Table 16: Storage, storage capacity, and losses after storage

\begin{tabular}{|c|c|c|c|c|c|c|}
\hline \multirow{2}{*}{ Types of Actors } & \multicolumn{2}{|c|}{ Storage (\%) } & \multirow{2}{*}{$\begin{array}{c}\text { How long } \\
\text { (Mean) }\end{array}$} & \multirow{2}{*}{$\begin{array}{c}\text { Storage } \\
\text { Quantity (Kg) }\end{array}$} & \multirow{2}{*}{$\begin{array}{c}\text { Losses } \\
(\mathbf{k g})\end{array}$} & \multirow{2}{*}{$\begin{array}{c}\text { Losse: } \\
{[\%]}\end{array}$} \\
\hline & Yes & No & & & & \\
\hline Wholesale & 44 & 56 & 1 & 124 & 6 & 4.83 \\
\hline Retailers & 100 & 0 & 1.5 & 75 & 4 & 5.33 \\
\hline Street vendors & 60 & 40 & 1 & 12 & 1.8 & 15.00 \\
\hline Restaurants & 0 & 100 & 0 & 0 & 0 & 0 \\
\hline
\end{tabular}

The findings show that all retailers $(100 \%)$ stored the products before selling to others, whereas only $44 \%$ of wholesalers and $60 \%$ of street vendors stored the products. On the contrary, restaurants did not store any vegetables: they purchased what they needed for each day. Where necessary, wholesalers generally stored the vegetables for no more than one day (an average of $124 \mathrm{~kg}$ ), whereas retailers often stored for 1 to 1.5 days (an average of $75 \mathrm{~kg}$ ), and street vendors stored for 1 day (an average of $12 \mathrm{~kg}$ ).
Though the storage duration for retailers and street vendor was similar (1 day), due to the lack of appropriate storage facilities, the postharvest losses for street vendors (15\%) were much higher than for the retailer $(5.33 \%)$ and wholesaler $(4.83 \%)$. Whereas no wholesalers expressed any concerns about food safety, only $30 \%$ of retailers, $50 \%$ of street vendors, and $20 \%$ of restaurant expressed a similar opinion (Table 16).

Table 17: Reason for vegetable spoilage after storage (\%)

\begin{tabular}{|l|c|c|c|c|c|}
\hline \multirow{2}{*}{ Reasons for Damage } & \multicolumn{4}{|c|}{ Percent [of respondents] } \\
\cline { 2 - 6 } & Wholesale & Retailer & Streetvendor & Rest. & Overall \\
\hline Low quality & 12.50 & 34.38 & 60.00 & 55.56 & 40.00 \\
\hline Damaged due to overloading & 50.00 & 40.63 & 20.00 & 11.11 & 36.36 \\
\hline Damaged during loading unloading & 0.00 & 28.13 & 40.00 & 22.22 & 27.27 \\
\hline Poor packaging & 0.00 & 31.25 & 20.00 & 0.00 & 23.64 \\
\hline Transport availability & 0.00 & 9.38 & 13.33 & 0.00 & 7.27 \\
\hline Rodents \& Insects & 0.00 & 6.25 & 13.33 & 11.11 & 7.27 \\
\hline No option for segregation before purchase & 0.00 & 9.38 & 6.67 & 0.00 & 7.27 \\
\hline Damaged due to transportation & 0.00 & 6.25 & 0.00 & 22.22 & 5.45 \\
\hline Lack of knowledge of loader unloader & 25.00 & 0.00 & 6.67 & 0.00 & 5.45 \\
\hline Temperature & 12.50 & 6.25 & 0.00 & 11.11 & 5.45 \\
\hline Rotten/spoilage & 0.00 & 6.25 & 6.67 & 22.22 & 8.64 \\
\hline Product quality & 0.00 & 6.25 & 6.67 & 11.11 & 3.64 \\
\hline Storage problem & 25.00 & 0.00 & 0.00 & 0.00 & 3.64 \\
\hline Open vehicle & 0.00 & 0.00 & 6.67 & 0.00 & 1.82 \\
\hline Buying in a lot & 0.00 & 3.13 & 0.00 & 0.00 & 1.82 \\
\hline Intentionally provide damaged product & 0.00 & 3.13 & 0.00 & 0.00 & 1.82 \\
\hline Shortage of labour & 12.50 & 3.13 & 0.00 & 0.00 & 1.82 \\
\hline
\end{tabular}

Overloading of vegetables $(41 \%)$ is considered a critical issue for retailers, followed by poor packaging (31\%). Improper loading and unloading (28\%) also contributed to the damage and thus the deterioration in quality. In addition, $9 \%$ of retailers stated that poor quality was the result of poor grading at the farm gate. Street vendors (60\%) and restaurants (57\%) were seriously affected by the low-quality products they purchased from wholesalers and traders. Street vendors suffered from product damage due to improper loading and unloading (40\%), followed by overloading (20\%) and poor packing (20\%). For the restaurants, the poor product quality was attributed to problems associated with improper loading and unloading (21\%), damaged due to poor transportation system $(21 \%)$, and rotten produce 
(21\%). Other issues contributing to the product damage included the lack of cool storage facilities, poor product quality, insect infestation, and overloading during transportation (11\%). BadrudDoza, (2006) reported that poor packaging and poor handling methods could contribute to as much as $40 \%$ of the losses incurred in the fresh vegetable industry. Singh and Chandha, (1990) reported that $25-40 \%$ of vegetable loss occurs due to rough prepackaging and improper postharvest handling, transportation, and storage practice. Sharma (1987) showed that postharvest losses of vegetables in Bangladesh could be as high as $43 \%$.

Table 18: Food Safety Concern among different stockholders

\begin{tabular}{|l|c|c|c|c|}
\hline \multirow{2}{*}{ Food safety concerns } & \multicolumn{3}{|c|}{ Percent [of respondents] } \\
\cline { 2 - 5 } & Wholesale & Retail & Streetvendor & Rest. \\
\hline No Idea & 100 & 30 & 50 & 20 \\
\hline Use of Formalin & 0 & 30 & 25 & 20 \\
\hline Chemical contamination & 0 & 20 & 25 & 0 \\
\hline Low Quality & 0 & 0 & 0 & 40 \\
\hline No knowledge of chemical used & 0 & 10 & 0 & 40 \\
\hline Insecticides/ Pesticides used & 0 & 10 & 25 & 0 \\
\hline Wash products with quality water & 0 & 0 & 0 & 0 \\
\hline No hidden issue & 0 & 0 & 0 \\
\hline
\end{tabular}

Retailers (30\%), street vendors (25\%), and restaurants (20\%) all expressed their concerns about the potential use of formalin. Chemical contamination was another food safety concern raised among the retailers (20\%) and street vendors (25\%). Restaurants were concerned about the low quality of vegetables (40\%) and the chemicals used (40\%). As street vendors often sprayed the products with water to retain their freshness, some issues were expressed about the use of non-potable water and the risk of contamination. No respondents in the vegetable supply chain had received any formal training in food safety management (Table 18).

All of the respondents under wholesale, retail, street hawker, and restaurant are not got any formal training on food safety or any relevant topics of food safety (Table 19).

Table 19: Food Safety Training

\begin{tabular}{|l|c|c|c|c|}
\hline \multirow{2}{*}{ Types of Response } & \multicolumn{4}{|c|}{ Formal training in food safety [percent] } \\
\cline { 2 - 5 } & Wholesale & Retailer & Streetvendor & Restaurant \\
\hline Yes & 0 & 0 & 0 & 0 \\
\hline No & 100 & 100 & 100 & 100 \\
\hline
\end{tabular}

Table 20: Major Risk associated with the vegetable business in Dhaka City

\begin{tabular}{|l|c|c|c|c|}
\hline \multirow{2}{*}{ Major risks } & \multicolumn{4}{|c|}{ Percent } \\
\cline { 2 - 5 } & Wholesale & Retailer & Streetvendor & Restaurant \\
\hline Rainwater & 37 & 30 & 42 & 20 \\
\hline Fire & 0 & 0 & 0 & 40 \\
\hline Flood & 62 & 70 & 48 & 0 \\
\hline Theft/ Robbery & 0 & 0 & 0 & 0 \\
\hline Rat & 0 & 0 & 0 & 0 \\
\hline Building Collapse & 0 & 0 & 0 & 0 \\
\hline
\end{tabular}

For wholesalers $(62 \%)$, retailers $(70 \%)$, and street vendors $(48 \%)$, flooding during the rainy season was the major risk to the business (Table 20). On the UniversePG I www.universepg.com other hand, restaurants were mostly affected by the risk of fire (40\%) and rodent infestation (40\%).The second most frequently cited risk for all stakeholders 
was rainwater in the rainy season. In conducting their business, wholesalers generally employed 3 full-time staff and as many as 5 part-time (or temporary) employees. While the retail sector generally only employed I full-time staff member and 1 part-time staff member, the restaurants employed as many as two full-time staff and up to 10 temporary employees (Table 20). Most of the respondents (49\%) involved in vegetable trading were aware of the weight and measurement act under
BSTI where each business person was responsible for the correct calibration of their measuring balance.

The need for a trading license (26\%) was the second most frequently cited regulation, followed by market price monitoring law or price control law (19\%). While several respondents were aware of the legislation banning the use of polythene bags (7\%), they continue to be used. Waste cleaning regulation in the market place was cited by another $7 \%$ of respondents (Table 21).

Table 21: Employment status in Vegetable Business in Dhaka City

\begin{tabular}{|l|c|c|c|c|}
\hline \multirow{2}{*}{ Types of Employee } & \multicolumn{4}{|c|}{ Mean (number of the employee) } \\
\cline { 2 - 5 } & Wholesale & Retailer & Street vendor & Restaurant \\
\hline Permanent employees & 3 & 1 & 0 & 2 \\
\hline Temporary employees & 5 & 1 & 0.15 & 10 \\
\hline
\end{tabular}

Table 22: Rules regulations of awareness.

\begin{tabular}{|l|c|}
\hline Types of Responses & Respondents (\%) \\
\hline Weights \& measuring act, Calibration & 48.84 \\
\hline Trade license & 25.58 \\
\hline Price control law & 18.60 \\
\hline No Idea & 16.28 \\
\hline Poly bag Uses regulation & 6.98 \\
\hline Waste cleaning & 6.98 \\
\hline Unknown & 6.98 \\
\hline Food Safety Law & 2.33 \\
\hline Formalin control act & 2.33 \\
\hline Food Contamination & 2.33 \\
\hline Control of pesticides \& Insecticides & 2.33 \\
\hline
\end{tabular}

Most of the respondents (49\%) involved in the vegetable business are fully aware of the weight and measurement act under BSTI where there is binding for each of the business persons to calibrate their measuring balance in a certain time for delivering the accurate weight of the products. Trade license $(26 \%)$ is the second-ranking regulation among the respondents followed by market price monitoring law or price control law (19\%). Few of them are also conscious about others implemented laws in Bangladesh like the uses of polythene bag (7\%), waste cleaning regulation from the market place (7\%), though they're a good amount respondent who is not aware of laws related with vegetable business $(16 \%)$.

Moreover, there is a good trend was observed among the vegetable business person regarding the food safety rules and regulations like food safety law (2\%), formalin control act (2\%), food contamination $(2 \%)$, control of chemical uses in vegetables and pesticide (2\%), (Table 22).

\section{CONCLUSION:}

Bangladesh is an agricultural country with a high potential to become a major fresh vegetable producer and exporter. The country, however, has failed to become an effective producer of these items. There is a huge worldwide demand for vegetables, and their consumption has increased due to proven health benefits. The vegetable traders' views have discussed the fact that insufficient infrastructure, a lack of training among growers and traders, and an informal and uncontrolled market are the reasons behind the failure. Policymakers should pay attention to the expansion of the country's vegetable production for 
local consumption and the export market. Several African studies have shown that small-scale vegetable farms can boost the financial condition of poor urban and rural households. The vegetable supply chain in the country should therefore be reorganized to meet the country's population's global standard of health and hygiene, poverty reduction, and export earnings.

Based on the findings of the study, the following conclusions are drawn-

- Vegetable production is in increasing trend but consumption percentage is not satisfactory in comparison to other countries. So, daunting task are ahead to achieve the targets.

- The marketing system is problematic and unorganized in Bangladesh. Adequate parking facilities in production areas or near the airport and cold storage facilities at the airport will be necessary before the business of fresh perishable produce export can be expanded.

\section{ACKNOWLEDGEMENTS:}

The authors are grateful to Dr. Anisur Rahman, Senior Supply Value Chain Expert of Food and Agriculture Organization (FAO) for his great support to meet with different vegetable supply chain involved stakeholders or actors in Dhaka city and vegetables growers'adjacent areas of Dhaka city and officials of Department of Agricultural Extension. The authors are also grateful to Dr. Peter Batt, Associated Professor, University of Perth, Australia to help for data analysis and also overall provide a good direction to accomplish this study.

\section{CONFLICT OF INTERESTS:}

The authors declare no conflict of interest.

\section{REFERENCES:}

1. Islam A.K.M.N. (2012). Conditions and Problems with Vegetables Marketing to Improve Farmers' Profitability in Bangladesh: A Qualitative Study in Kalatia Village, Journal of Rural Problems, 45(2), pp. 243247.

https://www.jstage.jst.go.jp/article/arfe/48/2/4 8_195/_pdf

2. BadrudDoza, A. F. (2006). Post-harvest Management of fruit and vegetables in the Asia Pacific Region, Published by Asian
Productivity Organization and FAO of the UN. Pp. 1-312.

https://www.apo-tokyo.org/00e-books/AG-18 PostHarvest/AG-18 PostHarvest.pdf

3. BadrudDoza A. F. (2006). Bangladesh. In: Rolle, RS Post-harvest management of fruit and vegetables in the Asia-Pacific.

4. Bangladesh Bureau of Statistics (BBS), (2015). Agricultural Census 2014.

5. Biswas, S.C. (2014). Vegetable cultivation in the monsoon season in Bangladesh. 15. https://www.academia.edu/27086052/Vegetabl e cultivation in the monsoon season in Ba ngladesh?auto $=$ download

6. Hassan, (2013). Improving the Marketing System Performance for Fruits and Vegetables in Bangladesh. Pp. 1-180. https://www.slideserve.com/minerva-shelton/ improving-the-marketing-system-performan ce-of-fruits-and-vegetables-in-bangladesh

7. Hassan MK, Chowdhury BLD and Akhter N. (2010). Post-Harvest loss assessment: A study to formulate policy for loss reduction of fruits and vegetables and socio-economic uplift of the stakeholders, NFPCSP. http://fpmu.gov.bd/agridrupal/sites/default/file s/Kamrul_Hassan-PR8-08.pdf

8. Hossain SM, Sarker C, and Mahmud S. (2019). Effect of plant growth regulator on the growth and high yield of heat tolerant tomato variety (Lycopersicon esculentum Mill). Am. J. Pure Appl. Sci., 1(5), 30-43. https://doi.org/10.34104/ajpab.019.019304

9. Hossain, M. A. (2011). Country case Bangladesh. Sub-Regional Workshop on Environmental Requirements, Market Access/Entry and Export Competitiveness for Horticultural Products from Bangladesh. Bangkok, Thailand.

http://fpmu.gov.bd/agridrupal/content/countrycase-study-environmental-requirements-mark et-accessentry-and-export-competitions-hor

10. Ali M. (2001). Vegetables in Bangladesh: Economic and Nutritional Impact of New Varieties and Technologies, AVRDC Technical Bulletin No. 25. Pp. 55. https://worldveg.tind.io/record/27977

11. Quasem, M. A. (2013). Exports of fresh horticultural crops from Bangladesh: problems and prospects. Dhaka: Bangladesh Institute of Development Studies. 
12. Quddus M. M. (2013). Examining the Production Performance of Vegetables for Business Development in Bangladesh.

13. Rahman, S. \& Pandey, M. S. (2014). Cold chain can save the food supply chain. The Daily Star, 16 September. Region (103-110). Asian Productivity Organization (APO). https://www.thedailystar.net/cold-chain-cansave-food-supply-chain-41858

14. Saleh, M. A. (2014). Constraints and Opportunities Facing the Horticultural Sector in Bangladesh. South Asia Enterprise Development Facility (SEDF)/International Finance Corporation, Bangladesh.

15. Singh, K. and Chadha K. L. (1990). Vegetable production and policy in Indian, in vegetable Research and Development in South Asia. Proceeding of a Workshop.

16. Sharma. S.K. (1987). Training manual of vegetable and social Forestry. Department of AgricultureExtension, Dhaka, Bangladesh.

17. Temesgen FA. (2020). The role of Ethiopia commodity exchange (ECX) in stimulating agricultural commodities export: a case study of export coffee, Can. J. Bus. Inf. Stud., 2(3), 54-65. https://doi.org/10.34104/cjbis.020.054065

18. United Nations Environment Programme, UNEP, (2015). Annual report 2015. 1-57. https://www.unenvironment.org/annualreport/ 2015/en/index.html

Citation: Hossain SM, Sarker C, Alam MM, Chowdhury KB, and Kamal MG. (2020). Investigation of vegetable market integration system in Dhaka city: a study on effective supply value chain analysis, Int. $J$. Manag. Account. 2(6), 131-146. https://doi.org/10.34104/ijma.020.01310146 @) 